\title{
PENDIDIKAN KARAKTER BERBASIS AL-QURAN
}

\author{
Dewi Purnama Sari \\ S3 UMY - Yogyakarta \\ fatiya.dewi@gmail.com
}

\begin{abstract}
Abstrak
Makalah ini membahas masalah tentang pendidikan karakter. Pendidikan karakter menjadi sorotan perhatian belakangan ini karena mengalami kemunduran yang mengakibatkan kemerosotan moral. Dalam al-Qur'an, karakter menggunakan term "akhlaq” yang diartikan kehendak yang dibiasakan. Kehendak dan kebiasaan menimbulkan kekuatan. Apabila kebiasaan menghasilkan suatu perbuatan baik disebut akhlakul karimah. Pendidikan karakter merupakan usaha secara sengaja untuk membantu pengembangan karakter dengan optimal. Pendidikan karakter tidak bisa hanya sekedar mentransfer ilmu pengetahuan atau melatih suatu keterampilan tertentu. Pendidikan karakter perlu proses, contoh teladan, dan pembiasaan atau pembudayaan dalam lingkungan peserta didik di lingkungan sekolah, keluarga, maupun lingkungan masyarakat. Pendidikan karakter dalam al-Qur'an perlu memperhatikan pentingnya dimensi penanaman akhlak terpuji (akhlakul karimah).
\end{abstract}

Kata kunci : pendidikan karakter, al-Qur'an, akhlakul karimah

\section{A. Pendahuluan}

Pendidikan karakter telah menjadi polemik di berbagai negara. Pandangan pro dan kontra mewarnai diskursus pendidikan karakter sejak lama. Sejatinya, pendidikan karakter merupakan bagian esensial yang menjadi tugas sekolah, tetapi selama ini kurang perhatian. Seyogyanya sekolah tidak hanya berkewajiban meningkatkan pencapaian akademis, tetapi juga bertanggung jawab dalam membentuk karakter peserta didik. Capaian akademis dan pembentukan karakter yang baik merupakan dua misi integral yang harus mendapat perhatian sekolah. Namun tuntutan ekonomi dan politik pendidikan menyebabkan penekanan pada pencapaian akademis mengalahkan idealitas peran sekolah dalam pembentukan karakter. ${ }^{1}$

Pendidikan karakter bukanlah sebuah gagasan yang baru. Sepanjang sejarah, di negara-negara di seluruh dunia, pendidikan memiliki dua tujuan besar ; membantu anakanak menjadi pintar dan membantu mereka menjadi baik. Pintar dan baik tidaklah sama. Sejak zaman Plato masyarakat yang bijak telah menjadikan pendidikan karakter sebagai tujuan sekolah. Mereka memberikan pendidikan karakter yang dibarengkan dengan pendidikan intelektual, kesusilaan dan literasi, serta budi pekerti dan pengetahuan. Mereka

\footnotetext{
${ }^{1}$ Zubaedi, Disain Pendidikan KarakterKonsepsi dan Aplikasinya dalam Lembaga Pendidikan, (Jakarta : Kencana, 2013), h. 14
} 
mencoba membentuk sebuah masyarakat yang menggunakan kecerdasan untuk kemaslahatan, dan mencoba membangun dunia lebih baik. ${ }^{2}$

Pendidikan karakter mengalami kemunduran mengakibatkan kemerosotan moral. Di antara kemerosotan moral yang terjadi adalah ; meningkatnya pergaulan seks bebas, tingginya angka kekerasan anak-anak dan remaja, kejahatan terhadap teman, pencurian remaja, kebiasaan menyontek, penyalahgunaan obat-obatan, pornografi, perkosaan, perampasan, dan perusakan hak milik orang lain menjadi masalah sosial yang hingga saat ini belum dapat diatasi secara tuntas.

Kondisi krisis dan dekadensi moral ini menandakan bahwa seluruh pengetahuan moral dan agama yang didapatkan dibangku sekolah ternyata tidak berdampak terhadap perubahan tingkah laku siswa. Banyak orang berpandangan bahwa kondisi demikian diduga berawal dari proses pembelajaran yang cenderung mengajarkan pendidikan moral sebatas teks dan kurang mempersiapkan siswa untuk menyikapi dan menghadapi kehidupan yang kontradiktif. Atas kondisi demikian pendidikan karakter mulai mendapat perhatian dari banyak pihak.

Pendidikan karakter di Indonesia pertama kali dicetuskan oleh Ratna Megawangi, alumnus IPB yang concern terhadap dunia pendidikan, anak dan perempuan. Melalui konsep pendidikan holistik berbasis karakter, Mengawangi mengedepankan sembilan karakter yang ingin dibangun. Istilah pendidikan karakter ini kembali menguat ketika Menteri Pendidikan dan Kebudayaan RI, Muhammad Nuh, dalam pidatonya pada Hari Pendidikan Nasional tahun 2011 menekankan pentingnya pendidikan karakter sebagai upaya pembangunan karakter bangsa. ${ }^{3}$

Bagaimana dengan pendidikan karakter berbasis al-Qur'an? Landasan pendidikan karakter dalam al-Qur'an terdapat dalam QS an-Nisa' ayat 9 :

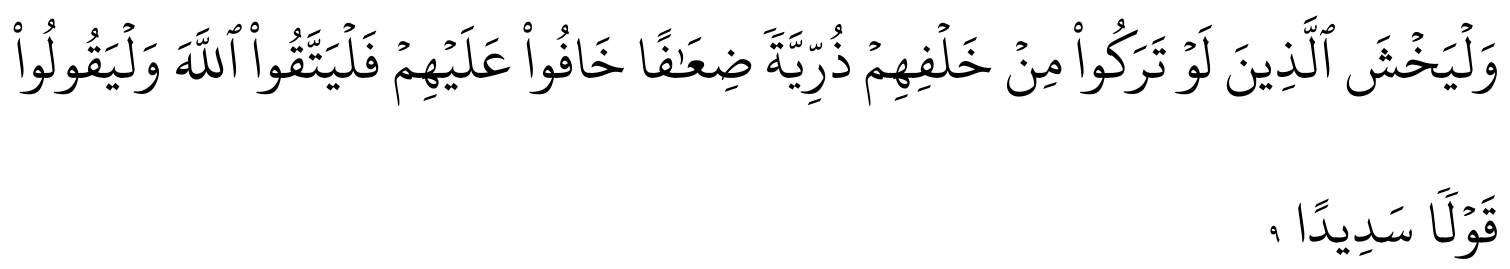

\footnotetext{
2 Thomas Lickona, Pendidikan Karakter Panduan Lengkap Mendidik Siswa Menjadi Baik dan Pintar, (Bandung: Nusa Media, 2014), h. 6

${ }^{3}$ Ulil Amri Syafri, Pendidikan Karakter Berbasis Al-Qur'an, (Jakarta : Rajagrafindo Persada, 2014), h. x
} 
Artinya : "Dan hendaklah takut kepada Allah orang-orang yang seandainya meninggalkan dibelakang mereka anak-anak yang lemah, yang mereka khawatir terhadap (kesejahteraan) mereka. oleh sebab itu hendaklah mereka bertakwa kepada Allah dan hendaklah mereka mengucapkan perkataan yang benar."

Dalam ayat tersebut Allah mengharuskan setiap umat tidak meninggalkan dibelakang mereka generasi yang lemah, tak berdaya dan tak memiliki daya saing dalam kompetisi kehidupan. Ayat ini juga dapat diartikan secara umum bahwa ada pesan alQur'an kepada setiap muslim untuk berupaya sekeras-kerasnya agar generasi sesudahnya merupakan generasi yang tangguh melebihi para pendahulunya. ${ }^{4}$

Dalam al-Qur'an kesempurnaan manusia tidak hanya terletak pada dimensi jasadiah semata, tetapi melalui dimensi rohaniahlah manusia akan senantiasa bertahan pada posisinya sebagai makhluk terbaik. Pengembangan pada sisi jasmaniah semata hanya akan menjatuhkan manusia ke tempat yang paling rendah (asfala safilin). Pengembangan dimensi rohaniah akan melahirkan akhlak terpuji. Makalah ini akan mencoba memaparkan bagaimana pendidikan karakter dalam perspektif al-Qur'an.

\section{B. Karakter}

Secara harfiah istilah karakter berasal dari bahasa Inggris "character" yang berarti watak, karakter, atau sifat. ${ }^{5}$ Dalam KBBI watak diartikan sebagai sifat batin manusia yang mempengaruhi segenap pikiran dan perbuatannya, atau berarti tabiat, dan budi pekerti. ${ }^{6}$ Karakter adalah tabiat, sifat-sifat kejiwaan, akhlak, atau budi pekerti yang membedakan seseorang dengan yang lain.

Karakter adalah "distinctive trait, distinctive quality, moral strength, the pattern of behavior found in an individual or group." "Character determines someone's private thought and someoen's perfect done. Good character is the inward motivation to do what is rigth, according to the highest standard of behavior in every situation. "Character is the sum of all the qualities that make you who you are. It's your values, your thoughts, your words, and your action. "7 Karakter merupakan serangkaian sikap, perilaku, motivasi, dan keterampilan untuk melakukan hal yang terbaik. Karakter adalah keseluruhan nilainilai, pemikiran, perkataan, dan perilaku atau perbuatan yang telah membentuk diri

\footnotetext{
${ }^{4}$ Kementerian Agama RI, Tafsir Qur'an Tematik Pendidikan, Pengembangan Karakter, dan Pengembangan Sumber Daya Manusia, (Jakarta : Badan Litbang dan Diklat, 2010), h. 11-12

${ }^{5}$ John M Echols dan Hasan Shadily, Kamus Inggris Inonesia, (Jakarta : Gramedia, 1979), h. 107

${ }^{6}$ Tim Penyusun, Kamus Besar Bahasa Indonesia, (Jakarta : Balai Pustaka, 2008), h.1811

${ }^{7}$ Zubaedi, Disain Pendidikan KarakterKonsepsi dan Aplikasinya dalam Lembaga Pendidikan,... h. 9
} 
seseorang. Karakter merupakan jati diri, kepribadian, dan watak yang melekat pada diri seseorang. Sebagai aspek kepribadian, karakter merupakan cerminan dari kepribadian secara utuh dari mentalitas, sikap, dan perilaku seseorang.

Wynne mengatakan karakter berasal dari bahasa Yunani yang berarti "to mark" (menandai) atau memfokuskan bagaimana mengaplikasikan nilai kebaikan dalam bentuk tindakan atau tingkah laku. Oleh sebab itu orang yang berperilaku tidak jujur, kejam, atau rakus dikatakan sebagai orang yang berkarakter jelek, sementara orang yang berperilaku jujur, suka menolong dikatakan sebagai orang yang berkarakter mulia. ${ }^{8}$ Istilah karakter erat kaitannya dengan kepribadian (personality) seseorang. Seseorang bisa disebut orang yang berkarakter (a person of character) apabila perilakunya sesuai dengan kaidah moral.

Menurut Joel Kuperman, karakter bermakna "instrument for making and graving, impress, stamp, distinctive mark, distinctive nature." Berkowtiz mengartikan karakter sebagai “an individual's set of psychological characteristic that affect person's ability and inclination to function morally." Karakter merupakan ciri yang melekat pada seseorang. Karakter menjadi tanda identifikasi. Wilhelm menyatakan "character can be measured corresponding to the individual's compliance to a behavioral standard or the individual's compliance to a set moral code." Karakter merepresentasikan identitas seseorang yang menunjukkan ketundukannya pada aturan atau standar moral dan termanifestasikan dalam tindakan.

Karakter yang baik : filosof Yunani Aristoteles mendefinisikan karakter yang baik sebagai hidup dengan tingkah laku yang benar. Tingkah laku benar dalam hal berhubungan dengan orang lain dan berhubungan dengan diri sendiri. Karakter terbentuk dari tiga bagian yang saling berkaitan ; pengetahuan moral (moral knowing), perasaan moral (moral feeling), dan perilaku moral (moral behavior). Karakter yang baik terdiri atas mengetahui kebaikan (knowing the good), menginginkan kebaikan (desiring the good), dan melakukan kebaikan (doing the good). Dalam hal ini diperlukan pembiasaan dalam pemikiran (habits of the mind), pembiasaan dalam hati (habits of heart), dan pembiasan dalam tindakan (habits of the action). ${ }^{9}$ Berdasarkan pendapat di atas dapat dikatakan bahwa karakter yang baik harus didukung oleh pengetahuan tentang kebaikan, keinginan untuk berbuat baik, dan kemampuan untuk melakukan perbuatan baik.

\footnotetext{
${ }^{8}$ E Mulyasa, Manajemen Pendidikan Karakter, (Jakarta : Bumi Aksara, 2011), h. 3

9 Thomas Lickona, Pendidikan Karakter Panduan Lengkap Mendidik Siswa Menjadi Baik dan Pintar, (Bandung: Nusa Media, 2014)
} 
Karakter seseorang berkembang berdasarkan potensi yang dibawa sejak lahir atau yang dikenal sebagai karakter dasar yang bersifat biologis. Menurut Ki Hajar Dewantara, aktualisasi karakter dalam bentuk perilaku sebagai hasil perpaduan antara karakter biologis dan hasil interaksi dengan lingkungannya. Karakter dapat dibentuk melalui pendidikan karena pendidikan merupakan alat yang paling efektif untuk menyadarkan individu dalam jati diri kemanusiaannya. Dengan pendidikan akan dihasilkan kualitas manusia yang memiliki kehalusan budi dan jiwa, memiliki kecemerlangan pikiran, kecekatan raga, dan memiliki kesadaran penciptaan dirinya. Dibanding faktor lain, pendidikan memberikan dampak dua atau tiga kali lebih kuat dalam pembentukan kualitas manusia.

Dalam al-Qur'an konsep karakter menggunakan term "akhlak" sebagaimana yang terdapat dalam hadits dan ayat sebagai berikut :

$$
\text { إنما بعثت لأتم صالح الاخلق }
$$

Artinya : "Sesungguhnya aku diutus untuk menyempurnakan akhlak yang sholeh". (HR Bukhari dalam shahih Bukhari kitab adab, Baihaqi dalam kitab syu'bil Iman dan Hakim).

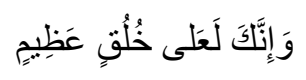

Artinya : "Dan sesungguhnya kamu benar-benar berbudi pekerti yang agung”. (QS alQalam ayat 4)

Akhlak menurut bahasa adalah bentuk jamak dari "khuluq" yang berarti sebuah kebiasaan dan perbuatan yang terus diulang. Huruf lam mengandung arti al-dien (kepercayaan), al-thab'u (karakter), dan al-sijiyyat (watak) yang intinya bermakna perasaan jiwa seseorang, naluri, sifat, dan arti-arti khusus yang ditampilkan dalam perilaku yang nyata, baik atau buruk, melahirkan penghargaan atau celaan. Hampir semua kamus bahasa Arab sepakat mendefinisikan al-khuluq sebagai sebuah kondisi perasaan jiwa yang kuat untuk menciptakan tindakan-tindakan tanpa membutuhkan pemikiran atau ide. ${ }^{10}$

Ahmad Amin mendefinisikan akhlak sebagai berikut :

10 Amri Rahman dan Dulsukmi Kasim, Pendidikan Karakter Berbasis al-Qur'an Upaya menciptakan Bangsa yang Berkarakter, Jurnal al-Ulum Vol. 14 No. 1 Juni 2014, h. 255 
Artinya: "Sebagian orang mengetahui bahwa yang disebut akhlak adalah kehendak yang dibiasakan. Artinya, kehendak itu bila membiasakan sesuatu, kebiasaan itu dinamakan akhlak:". ${ }^{11}$

Berdasarkan pendapat Ahmad Amin di atas, kehendak merupakan ketentuan dari beberapa keinginan manusia setelah bimbang. Sedangkan kebiasaan merupakan perbuatan yang diulang-ulang sehingga mudah melakukannya. Masing-masing dari kehendak dan kebiasaan ini mempunyai kekuatan, dan gabungan dari kehendak dan kebiasaan ini menimbulkan kekuatan yang lebih besar. Kekuatan yang besar inilah yang disebut akhlak. Apabila kebiasaan menghasilkan suatu perbuatan baik disebut akhlakul karimah, bila menghasilkan perbuatan buruk disebut akhlakul mazmumah.

Menurut Philip K Hitti ada tiga cara pandang yang berbeda di kalangan Islam melihat persoalan akhlak. Pertama, melihat akhlak dalam hubungannya dengan tertib sopan sehari-hari (popular philosophy of morality). Kedua, melihat akhlak dalam hubungannya dengan pengetahuan (philosophical). Ketiga, melihat akhlak dalam hubungannya dengan masalah kejiwaan (mystical psychological). Secara sederhana dapat dikatakan dalam membahas tingkah laku manusia menggunakan pendekatan teoritis dan praktis. Pendekatan yang bersifat teoritis merupakan bagian dari usaha rasionalisasi terhadap tingkah laku manusia berupa pikiran-pikiran logis tentang sesuatu yang harus diperbuat oleh manusia. Sedangkan pendekatan praktis menunjuk secara langsung tingkah laku manusia. Tingkah laku ini bisa dilihat sebagai hasil pikiran logis manusia ketika menyadari kehidupan sosialnya. Misalnya mana perbuatan yang harus dilakukan, mana perbuatan yang mesti ditinggalkan, mana perbuatan yang baik, serta mana perbuatan yang buruk. $^{12}$

Namun demikian haruslah dipahami bahwa pembicaraan mengenai akhlak tidak semata-mata merujuk kepada masalah kesopanan belaka, melainkan merujuk kepada pengertian yang lebih mendasar berkaitan dengan pandangan hidup tentang baik dan buruk, benar dan salah. Oleh karena itu, menurut Quraish Shihab, akhlak dalam agama Islam tidak dapat disamakan dengan etika atau moral jika pengertiannya hanya semata merujuk kepada sopan santun di antara manusia serta hanya berkaitan dengan tingkah laku lahiriah. Akhlak dalam Islam memiliki makna yang lebih luas yang mencakup beberapa hal yang tidak merupakan sifat lahiriah. Akhlak Islam berkaitan dengan sikap batin

${ }^{11}$ Zahrudin Ar dan Hasanuddin Sinaga, Pengantar Studi Akhlak, (Jakarta : Rajawali, 2004), h. 4

12 Ajat Sudrajat, Pendidikan Moral dalam Perspektif Islam, Jurnal Dinamika Pendidikan No. 1 Tahun IX Maret 2002, h. 21 
maupun pikiran. Akhlak Islam juga memiliki cakupan yang lebih luas karena tidak semata mengatur hubungan manusia denga manusia. Akhlak Islam mencakup hubungan manusia dengan Allah, hubungan manusia dengan manusia, serta hubungan manusia dengan makhlak lainnya. ${ }^{13}$

Karena akhlak merupakan satu kesatuan utuh dari ajaran Islam, maka akhlak dalam Islam mendasarkan kaidah-kaidahnya tentang baik-buruk, benar-salah, bersumberkan kepada ajaran Allah. Tolok ukur kelakuan baik dan buruk mestilah merujuk kepada ketentuan Allah. Diyakini sepenuhnya bahwa apa yang dinilai baik oleh Allah pasti baik dalam esensinya. Demikian pula sebaliknya, tidak mungkin Allah menilai kebohongan sebagai kelakuan baik, karena kebohongan esensinya adalah buruk.

Dalam al-Qur'an, karakter yang baik merupakan interaksi seluruh totalitas manusia, bukan nalar saja, tapi gabungan antara nalar dengan kesadaran moral dan kesucian jiwa. Karena itu karakter yang terpuji adalah hasil internalisasi nilai-nilai agama dan moral pada diri seseorang yang ditandai oleh sikap dan perilaku positif. Beberapa karakter utama yang melandasi karakter-karakter baik lainnya yang terdapat dalam alQur'an adalah ; a) tabah dan pantang menyerah di dalamnya meliputi sabar, baik sabar secara pasif maupun sabar secara aktif, b) konsisten (istiqamah) yang konsekuensinya tidak mengikuti hawa nafsu, baik yang muncul dari dirinya maupun keinginan buruk orang lain, c) integritas yang dibangun dari disiplin diri, disiplin untuk jujur, adil sebagaimana mestinya di setiap situasi, d) profesionalime yang melahirkan mentalitas mutu, mentalitas altruistik, mentalitas pembelajar, dan mentalitas etis. ${ }^{14}$

\section{Pendidikan Karakter}

Pendidikan karakter diartikan sebagai "the delibrete us of all dimensions of school life to foster optimal character development", ${ }^{15}$ (usaha secara sengaja dari seluruh kehidupan dimensi sekolah untuk membantu pengembangan karakter dengan optimal). Hal ini berarti untuk mendukung perkembangan karakter peserta didik harus melibatkan seluruh komponen di sekolah baik dari aspek isi kurikulum (the contet of the curriculum), proses pembelajaran (the procces of instruction), kualitas hubungan (the quality of

\footnotetext{
${ }^{13}$ M Quraish Shihab, Wawasan Al-Qur'an, (Bandung : Mizan, 1996), h. 261

14 Kementerian Agama RI, Tafsir Qur'an Tematik Pendidikan, Pengembangan Karakter, dan Pengembangan Sumber Daya Manusia,... h. 134-162

${ }^{15}$ Suparlan, Pendidikan Karakter Sedemikian Pentingkah dan Apakah yang Harus Kita Lakukan, dalam Suparlan.com dipublikasikan 15 Oktober 2010
} 
relationship), penanganan mata pelajaran (the handling of discipline), serta etos seluruh lingkungan sekolah.

Pendidikan karakter juga didefinisikan "the deliberate effort to cultivate virtue that is objectively good human qualities that are good for the individual person and good for the whole society", ${ }^{16}$ (usaha sengaja untuk mewujudkan kebajikan yaitu kualitas kemanusiaan yang baik secara objektif, bukan hanya untuk individu perseorangan, tetapi juga baik untuk masyarakat secara keseluruhan).

Menurut David Elkind \& Freddy Sweet, "character education is the deliberate effort to help people understand, care about, and act upon core ethicall value", ${ }^{17}$ (pendidikan karakter adalah usaha sengaja untuk membantu manusia memahami, peduli tentang, dan melaksanakan nilai-nilai etika inti).

Lebih lanjut David Elkind \& Freddy Sweet mengatakan, "when we think about the kind of character we want for our children, it is clear that we want them to be able to judge what is right, care deeply about what is right, and than do what they believe to be right, event in the first pressure from without and temptation from within", ${ }^{18}$ (ketika berpikir tentang jenis karakter yang dinginkan bagi anak-anak, maka jelas bahwa kita mengharapkan mereka mampu menilai apakah kebenaran, peduli secara sungguh-sungguh terhadap kebenaran, dan kemudian mengerjakan apa yang diyakini sebagai kebenaran, bahkan ketika menghadapi tekanan dari luar dan upaya dari dalam).

Williams \& Schnaps mendefinisikan, "character eduation is any deleberate approach by which school personnel, often in conjuction with parents and community members, help children and youth become caring, principled and responsible", ${ }^{19}$ (pendidikan karakter merupakan berbagai usaha yang dilakukan oleh para personel sekolah, bersama-sama dengan orang tua dan anggota masyarakat, untuk membantu anakanak dan remaja menjadi atau memiliki sifat peduli, berpendirian, dan bertanggung jawab).

Dalam nuansa bimbingan dan konseling menurut American School Counselor menyatakan tujuan pendidikan karakter, "assist students in becaming positive and selfdircted in their lives and education and in striving toward future goals, ${ }^{20}$ (membantu

\footnotetext{
${ }^{16}$ Suparlan, ...Ibid.

${ }^{17}$ Suparlan, ...Ibid.

${ }^{18}$ Suparlan, ...Ibid.

${ }^{19}$ Suparlan, ...Ibid.

${ }^{20}$ Muhammad Nur Wangid, Peran Konselor Sekolah dalam Pendidikan Karakter, Artikel dalam Cakrawala Pendidikan (Yogyakarta : UNY, Mei 2010, Th. XXIX, Edisi Khusus Dies Natalis UNY), h. 174-175
} 
siswa menjadi lebih positif dan mampu mengarahkan diri dalam pendidikan dan kehidupan, dan berusaha keras dalam pencapaian tujuan masa depannya).

Dari beberapa pendapat di atas dapat dipahami bahwa pendidikan karakter merupakan upaya penanaman kecerdasan dalam berpikir, penghayatan dalam bentuk sikap, dan pengamalan dalam bentuk perilaku yang sesuai dengan nilai-nilai luhur yang menjadi jati dirinya. Diwujudkan dalam interaksi dengan Tuhannya, diri sendiri, antarsesama, dan lingkungannya. Nilai-nilai luhur tersebut antara lain ; kejujuran, kemandirian, sopan santun, kemuliaan sosial, kecerdasan berpikir dan berpikir logis. Penanaman pendidikan karakter tidak bisa hanya sekedar mentransfer ilmu pengetahuan atau melatih suatu keterampilan tertentu. Penanaman pendidikan karakter perlu proses, contoh teladan, dan pembiasaan atau pembudayaan dalam lingkungan peserta didik di lingkungan sekolah, keluarga, maupun lingkungan masyarakat.

Dalam al-Qur'an pendidikan karakter bertujuan untuk :

1. Mengeluarkan dan membebaskan manusia dari kehidupan yang gelap (tersesat) kepada kehidupan yang terang (lurus) (QS al-Ahzab ayat 43).

2. Menunjukkan manusia dari kehidupan yang keliru kepada kehidupan yang benar (QS al-Jumu'ah ayat 2).

3. Mendamaikan manusia yang bermusuhan menjadi bersaudara, menyelamatkan manusia yang berada di tepi jurang kehancuran, serta menjadi manusia yang selamat dunia dan akhirat (QS ali-Imran ayat 3). ${ }^{21}$

\section{Pendidikan Karakter dalam Al-Qu'ran}

\section{Dimensi-dimensi Pendidikan Karakter}

Disadari bahwa karakter/akhlak/moral yang dimiliki manusia bersifat fleksibel atau luwes serta bisa diubah atau dibentuk. Karakter/akhlak/moral manusia suatu saat bisa baik tetapi pada saat lain sebaliknya menjadi jahat. Perubahan ini tergantung bagaimana proses interaksi antara potensi dan sifat alami yang dimiliki manusia dengan kondisi lingkungan, sosial budaya, pendidikan, dan alam.

Pendidikan karakter di Indonesia didasarkan pada sembilan pilar karakter dasar. Karakter dasar menjadi tujuan pendidikan karakter. Kesembilan pilar karakter dasar ini adalah ; a) cinta kepada Allah dan semesta beserta isinya, b) tanggung jawab, disiplin, dan mandiri c) jujur, d) hormat dan santun, e) kasih sayang, peduli, dan kerja sama f) percaya

21 Amri Rahman dan Dulsukmi Kasim, Pendidikan Karakter Berbasis al-Qur'an Upaya menciptakan Bangsa yang Berkarakter,... h. 261 
diri, kreatif, kerja keras, dan pantang menyerah, g) keadilan dan kepemimpinan, h) baik dan rendah hati, dan i) toleransi. ${ }^{22}$ Sedangkan menurut Michele Borba ada tujuh nilai kebajikan yang perlu diajarkan pada anak agar anak bermoral tinggi, yaitu ; a) empati, b) hati nurani, c) kontrol diri, d) rasa hormat, e) kebaikan hati, f) toleransi, dan g) keadilan. ${ }^{23}$

Dalam pendidikan karakter berbasis Al-Qur'an, materi pendidikan karakter secara garis besar dapat dikelompokkan dalam tiga dimensi nilai akhlak, yaitu ; akhlak terhadap Allah, akhlak terhadap sesama manusia, dan akhlak terhadap alam semesta. ${ }^{24}$ Ruang lingkup akhlak terhadap Allah meliputi ; a) mengenal Allah, b) berhubungan dengan Allah, dan c) meminta tolong kepada Allah. Ruang lingkup akhlak terhadap manusia mencakup ; a) akhlak terhadap orang tua, b) akhlak terhadap saudara, c) akhlak terhadap tetangga, dan d) akhlak terhadap lingkungan masyarakat. ${ }^{25}$ Bagian ketiga adalah akhlak terhadap alam sekitar. Akhlak manusia terhadap alam bukan hanya semata-mata untuk kepentingan alam, tetapi jauh dari itu untuk memelihara, melestarikan, dan sekaligus untuk memakmurkan manusia. Hubungan manusia dengan alam bukan hubungan antara penakluk dengan yang ditaklukkan, tetapi hubungan kebersamaan dalam ketundukan kepada Allah. Hal ini karena kemampuan manusia dalam mengelola bukanlah akibat kekuatan yang dimiliki, tetapi akibat anugerah Allah. ${ }^{26}$

Tiga dimensi akhlak di atas menjadi materi yang mengisi pendidikan karakter. Atas pemikiran tersebut, pendidikan karakter perlu memperhatikan pentingnya dimensi penanaman akhlak terpuji (akhlakul karimah). Menurut Hamka, akhlak yang terpuji berarti sifat-sifat atau tingkah laku yang sesuai dengan norma-norma atau ajaran Islam. Akhlak terpuji berisi sikap taat, baik taat secara lahiriah maupun taat secara batiniah. Taat secara lahir berarti melakukan seluruh amal ibadah yang diwajibkan Allah, termasuk berbuat baik kepada sesama manusia dan lingkungan. Beberapa perbuatan yang dikategorikan taat lahiriah adalah :

a) Taubat, dikategorikan taat lahir dilihat dari sikap dan tingkah laku seseorang. Namun sifat penyesalan merupakan taat batin.

b) Amar ma'ruf nahi mungkar, perbuatan yang dilakukan kepada manusia untuk menjalankan kebaikan dan meninggalkan kemungkaran.

${ }^{22}$ Zubaedi, Disain Pendidikan KarakterKonsepsi dan Aplikasinya dalam Lembaga Pendidikan,... h. 72

${ }^{23}$ Michele Borba, Building Moral Intelligence The Seven Essensial Virtues that Teach Kids to Do The Right Thing, (Jakarta : Gramdeia, 2008), h. 7

${ }^{24}$ Zubaedi, Disain Pendidikan KarakterKonsepsi dan Aplikasinya dalam Lembaga Pendidikan,... h. 84

${ }^{25}$ M Yatimin Abdullah, Studi Akhlak dalam Persektif Al-Qur'an, (Jakarta : Amzah, 2007), h. 221

${ }^{26}$ M Quraish Shihab, Membumikan Al-Quran, (Bandung : Mizan, 1998), h. 295 
c) Syukur, berterima kasih terhadap nikmat yang telah dianugerahkan Allah kepada manusia dan seluruh makhluknya. ${ }^{27}$

Taat batin adalah segala sifat yang baik, yang terpuji yang dilakukan oleh anggota batin (hati). Yang termasuk taat batin adalah :

a) Tawakal, yaitu berserah diri sepenuhnya kepada Allah dalam menghadapi, menanti, atau menunggu hasil pekerjaan.

b) Sabar, yaitu sabar dalam beribadah, sabar ketika ditimpa musibah, sabar terhadap kehidupan dunia, sabar terhadap maksiat, dan sabar dalam perjuangan. Dasarnya adalah keyakinan bahwa semua yang dihadapi adalah ujian dan cobaan dari Allah.

c) Qana'ah, yaitu merasa cukup dan rela dengan pemberian yang dianugerahkan Allah. Qana'ah meliputi menerima dengan rela apa yang ada, memohon kepada Allah tambahan yang pantas dan ikhtiar, menerima dengan sabar akan keentuan Allah, bertawakal kepada Allah, serta tidak tertarik oleh tipu daya dunia. ${ }^{28}$

Secara esensial pendidikan karakter perlu mengupayakan penanaman akhlak terpuji dan pengendalian bahkan pembersihan dari akhlak tercela. Menurut al-Ghazali ada dua jenis akhlak yang perlu mendapat perhatian ketika seseorang mendesain isi pendidikan karakter, yaitu akhlak yang baik (akhlakul mahmudah) dan akhlak yang buruk (akhlakul madzmumah). Akhlak mahmudah adalah segala macam tingkah laku yang baik. Adapun yang termasuk sifat-sifat mahmudah adalah ; a) al-amanah (setia, jujur, dapat dipercaya), b) as-sidqu (benar, jujur), c) al-'adl (adil), d) al-'afwu (pemaaf), e) al-alifah (disenangi), f) al-wafa' (menepati janji), g) al-haya' (malu), h) ar-rifqu (lemah lembut), i) anisatun (bermuka manis) $)^{29}$

Adapun sifat-sifat madzmumah adalah sebagai berikut : a) ananiah (egoistis), b) albaghyu (melacur), c) al-buhtan (dusta), d) al-khianah (khianat), e) az-zulmu (aniaya), f) al-ghibah (mengumpat), g) al-hasad (dengki), h) al-kufran (mengingkari nikmat), i) arriya' (ingin dipuji), j) an-namimah (adu domba). ${ }^{30}$

Akhlak terpuji termanifestasi dalam bentuk-bentuk perilaku sebagai berikut : a) bersifat sabar, b) bersifat istiqamah, c) memelihara amanah, d) bersifat adil, e) bersifat

\footnotetext{
${ }^{27}$ Hamka, Tasawuf Modern, (Jakarta : Yayasan Nurul Islam, 1981), h. 179

${ }^{28}$ Hamka, Tasawuf Modern,... h. 180

${ }^{29}$ M Yatimin Abdullah, Studi Akhlak..., h. 25-26

${ }^{30}$ M Yatimin Abdullah, Studi Akhlak..., h. 26
} 
kasih sayang, f) bersifat hemat, g) bersifat berani, h) bersifat kuat, i) bersifat malu, j) menjaga kesucian diri, k) menepati janji ${ }^{31}$

Dengan demikian jelaslah bahwa dalam pendidikan karakter berbasis Al-Qur'an dimensi-dimensi karakter yang dikembangkan lebih mengacu pada akhlakul karimah yang bersumber pada Al-Qur'an. Inti dari akhlakul karimah adalah bersifat taat, dan ketaatan ini tidak hanya bersifat lahiriah tetapi juga bersifat batiniah. Ketaatan lahiriah dan ketaatan batiniah akan melahirkan akhlak terpuji yang termanifestasi dalam bentuk-bentuk perilaku tertentu.

2. Tahapan-tahapan dan Peran Keluarga dalam Pendidikan Karakter

Karakter seperti juga kualitas diri yang lainnya, tidak berkembang dengan sendirinya. Perkembangan karakter pada setiap individu dipengaruhi oleh faktor bawaan (nature) dan faktor lingkungan (nurture). Menurut psikologi perkembangan, setiap manusia memiliki potensi bawaan yang akan termanifestasi setelah dilahirkan termasuk potensi karakter. Menurut Confusius, seorang filosof Cina, manusia pada dasarnya memiliki potensi mencintai kebajikan. Namun apabila potensi ini tidak diikuti dengan pendidikan dan sosialisasi setelah manusia dilahirkan, maka manusia dapat berubah menjadi binatang, bahkan lebih buruk lagi. Oleh karena itu, sosialisasi dan pendidikan anak yang berkaitan dengan nilai-nilai kebajikan baik di keluarga maupun di sekolah dan lingkungan yang lebih luas, sangat penting dalam pembentukan karakter anak. ${ }^{32}$

Jika sosialisasi dan pendidikan (faktor nurture) sangat penting dalam pendidikan karakter, maka sejak kapan sebaiknya hal itu dilakukan? Menurut Erickson sejak usia dini. Erickson menyebutkan bahwa anak adalah gambaran awal manusia menjadi manusia, yaitu masa di mana kebajikan berkembang secara perlahan tapi pasti. Dengan kata lain, bila dasar-dasar kebajikan gagal ditanamkan pada anak usia dini, maka dia akan menjadi orang dewasa yang tidak memiliki nilai-nilai kebajikan. Usia dua tahun pertama dalam kehidupan adalah masa kritis bagi pembentukan pola penyesuaian pribadi dan sosial. Sikap, kebiasaan dan pola perilaku yang dibentuk pada awal kehidupan cenderung bersifat mapan, tetapi bukan berarti tidak dapat berubah. Ada tiga kkondisi yang memungkinkan perubahan terjadi, yaitu ; a) individu memperoleh bantuan atau bimbingan, b)

${ }^{31}$ M Yatimin Abdullah, Studi Akhlak..., h. 46

${ }^{32}$ Melly Latifah, Peranan Keluarga dalam Pendidikan Karakter Anak,... h. 2 
memperlakukan individu dengan cara-cara baru atau berbeda, dan c) ada motivasi yang kuat dari individu itu sendiri untuk membuat perubahan. ${ }^{33}$

Pengembangan karakter sebagai proses yang tiada henti terbagi menjadi 4 tahap :

a) Tahap pertama : pada usia dini disebut sebagai tahap pembentukan

b) Tahap kedua : pada usia remaja disebut sebagai tahap pengembangan

c) Tahap ketiga : pada usia dewasa disebut sebagai tahap pemantapan

d) Tahap keempat : pada usia tua disebut sebagai tahap pembijaksanaan

Perkembangan karakter sangat erat kaitannya dengan perkembangan moral. Moral adalah kebiasaan atau aturan yang harus dipatuhi oleh seseorang dalam berinteraksi dengan orang lain. ${ }^{34}$ Moral merupakan seperangkat aturan yang menyangkut baik atau buruk, pantas atau tidak pantas, benar atau salah yang harus dilaksanakan dalam kehidupan sosial. ${ }^{35}$ Perkembangan moral (moral development) berhubungan dengan peraturanperaturan dan nilai-nilai mengenai apa yang harus dilakukan seseorang dalam interaksinya dengan orang lain. ${ }^{36}$

Menurut teori social-learning perkembangan moral berlangsung melalui proses latihan dan peniruan. ${ }^{37}$ Anak berkembang moralnya apabila dalam sejarah kehidupannya ia dapat meniru orang di sekitarnya bertingkah laku moral dan sekaligus dilatih melakukan tingkah laku moral. Dalam proses peniruan, anak mengenal tingkah laku moral dengan jalan mengamati tingkah laku orang tua dan orang dewasa lainnya. Oleh karena itu interaksi yang bermoral dengan orang tua dan guru serta orang dewasa umumnya sangat penting pengaruhnya untuk perkembangan moral anak.

Menurut teori kognitif, Piaget menekankan bahwa perkembangan moral erat kaitannya dengan perkembangan kognitif. ${ }^{38}$ Anak-anak awal (0-7 tahun) berada pada tahap pramoralitas (prakonvensional), anak memahami tingkah laku baik, benar, atau pantas tergantung pada apakah tingkah laku itu memuaskan atau menimbulkan kemikmatan pada diri sendiri atau orang lain. Anak-anak akhir (7-15 tahun) berada pada tahap moralitas (konvensional), perkembangan moral ditandai oleh pemahaman anak bahwa tingkah laku yang baik atau benar adalah menaati aturan-aturan dan hukum-hukum yang telah

\footnotetext{
${ }^{33}$ Hurlock, Elizabeth B, Psikologi Perkembangan Suatu Pendekatan Sepanjang Rentang Kehidupan, (Jakarta : Erlangga, 2004), h. 5-6

${ }^{34}$ Depdikbud, Kamus Besar Bahasa Indonesia, (Jakarta : Balai Pustaka, 1995), h. 830

${ }^{35}$ M Daud Ali, Pendidikan Agama Islam, (Jakarta : Raja Grafindo Persada, 1998), h. 353

${ }^{36}$ John W Santrock, Adolescence, (Jakarta : Erlangga, 2006), h. 439

${ }^{37}$ John W Santrock, Perkembangan Masa Hidup Jilid I, (Jakarta : Erlangga, 2003), h. 46

${ }^{38}$ Ibid., h. 44
} 
disepakati dalam kehidupan bermasyarakat. Tingkah laku yang baik dan benar adalah melakukan kewajiban, kepatuhan terhadap kekuasaan hukum dan semua adalah untuk kepentingan dirinya sendiri dan orang lain. Anak mulai menghargai dan menghormati hakhak dan kepentingan orang lain. Remaja (15-19 tahun) berada pada tahap moralitas dengan penerimaan prinsip-prinsip moral (postkonvensional). Remaja mulai memahami nilai-nilai moral dan prinsip-prinsip moral yang merupakan standar kebenaran yang benar, namun nilai-nilai itu dapat saja bertentangan dengan apa yang terjadi dalam kehidupan masyarakat. Keadaan seperti ini dapat membingungkan remaja sehingga terjadi "konflik kebingungan moral". Konflik kebingungan moral menjadi penyebab tingkah laku nakal atau tingkah laku menyimpang.

Untuk membentuk karakter anak diperlukan syarat-syarat mendasar bagi terbentuknya kepribadian yang baik. Ada tiga kebutuhan dasar anak yang harus dipenuhi, yaitu :

a) Maternal bonding (kelekatan psikologis dengan ibu) merupakan dasar penting dalam pembentukan karakter anak karena aspek ini berperan dalam pembentukan dasar kepercayaan (trust). Kelekatan ini membuat anak merasa diperhatikan dan menumbuhkan rasa aman sehingga menumbuhkan rasa percaya.

b) Kebutuhan akan rasa aman, yaitu kebutuhan anak akan lingkungan yang aman dan stabil. Lingkungan yang berubah-ubah akan membahayan perkembangan emosi bayi. Pengasuh yang berganti-ganti juga akan berpengaruh negatif pada perkembangan emosi anak.

c) Kebutuhan akan stimulasi fisik dan mental. Hal ini membutuhkan perhatian yang besar dari orang tua. Menurut hasil penelitian, seorang ibu yang sangat perhatian (diukur dari seringnya ibu melihat mata anaknya, mengelus, menggendong, dan berbicara kepada anaknya pada usia di bawah enam bulan) akan mempengaruhi sikap bayinya sehingga menjadi anak yang gembira, antusias, dan menjadi anak yang kreatif. ${ }^{39}$

Menurut al-Ghazali, bila anak sudah mencapai usia sekolah, maka kewajiban orang tua adalah menyekolahkan di lembaga pendidikan yang bermutu, terutama untuk diajari al-Quran, Hadis dan materi-materi yang bermanfaat. Anak perlu dibimbing agar tidak terperosok pada perilaku yang jelek serta diberikan pujian dan ganjaran (reward) jika menunjukkan perilaku positif. Jika anak melakukan kesalahan jangan dibukakan di depan

${ }^{39}$ Melly Latifah, Peranan Keluarga dalam Pendidikan Karakter Anak,... h. 4 
umum. Bila mengulanginya lagi, diberi ancaman dan sanksi yang lebih berat dari yang semestinya. Anak diberi kesempatan untuk istirahat dan bermain, karena permainan bisa menjadi sarana mendidik selain sebagai hiburan. ${ }^{40}$

Pendidikan karakter berawal dari institusi pendidikan informal dalam lingkup keluarga, melalui pemeliharaan, pemberian kasih sayang, pembiasaan, dan pemberian makanan yang dikonsumsi. Bila anak telah mulai tampak daya khayalnya untuk membedabedakan sesuatu (tamyiz), maka ia perlu diberi pengertian dan pembiasaan pada hal-hal yang positif. Al-Ghazali juga menganjurkan metode cerita (qisah-hikayat) dan keteladanan (uswah al hasanah). Pada sisi lain orang tua perlu mengawasi pergaulan anak, karena pergaulan dan lingkungan itu memiliki andil sangat besar dalam pembentukan kepribadian anak. $^{41}$

Muhammad Quthb juga menyatakan bahwa metode dalam mendidik anak dapat menerapkan keteladanan, nasehat, hukuman, cerita, dan pembiasaan. Bakat anak juga perlu digali dan disalurkan dengan berbagai kegiatan positif untuk mengsi waktu luang yang dimiliki anak. Hal ini sebagai implementasi Hadis Nabi agar anak didik memanah, berenang, dan menunggang kuda. Perhatian al-Ghazali pada faktor makanan baik orang tua atau anak merupakan hal yang menarik. Hal ini mengingat makanan yang masuk ke dalam perut seseorang diyakini akan berpengaruh terhadap pembentukan genetika. Makanan yang halal akan menghasilkan gen yang baik dan sebaliknya makanan yang haram akan menghasilkan gen yang buruk.

Dalam mengembangkan karakter melalui pendidikan formal, harus didasarkan pada beberapa prinsip dan strategi. Di antaranya adalah ; a) menggunakan prinsip keteladanan dari semua pihak, baik orang tua, guru, masyarakat maupun pemimpin, b) menggunakan prinsip kontiniutas dan rutinitas, yaitu berupa pembiasaan secara terus menerus dalam segala aspek kehidupan, dan c) menggunakan prinsip kesadaran, yaitu kesadaran untuk bertindak sesuai dengan nilai-nilai karakter yang diajarkan. Salah satu strategi yang sangat perlu diperhatikan dalam pendidikan karakter adalah menciptakan lingkungan belajar yang kondusif sehingga anak dapat belajar dengan efektif di dalam

40 Hamdani Rizal dan Saifuddin Zuhri, Pemikiran al-Ghazali tentang Pendidikan Akhlak, dalam eprints.ums.ac.id

${ }^{41}$ Hamdani Rizal dan Saifuddin Zuhri, Pemikiran al-Ghazali tentang Pendidikan Akhlak,...Ibid. 
suasana yang memberikan rasa aman, penghargaan tanpa ancaman, dan memberikan semangat. ${ }^{42}$

Ditambahkan oleh al-Ghazali, untuk pendidikan formal mensyaratkan adanya seorang guru atau mursyid yang mempunyai kewajiban antara lain ; mencontoh Rasulullah tidak meminta imbalan, bertanggung jawab atas keilmuannya. Hendaklah membatasi pelajaran menurut pemahaman mereka. Hendaklah seorang guru mengamalkan ilmu yang amal itu dilihat oleh mata dan dilihat oleh hati.

Pengembangan karakter merupakan proses seumur hidup. Pengembangan karakter anak merupakan upaya yang perlu melibatkan semua pihak, baik keluarga, sekolah, masyarakat, maupun pemerintah. Keluarga merupakan basis pendidikan karakter. Maka tidak salah kalau krisis karakter yang terjadi di Indonesia sekarang ini dapat dilihat sebagai salah satu cerminan gagalnya pendidikan di keluarga.

Pada keluarga inti, peranan utama pendidikan karakter terletak pada ayah-ibu. Keluarga hendaknya menjadi sekolah untuk kasih sayang, atau tempat belajar yang penuh cinta dan kasih sayang. Ada tiga peran utama yang dapat dilakukan ayah-ibu dalam mengembangkan karakter anak, yaitu :

a) Berkewajiban menciptakan suasana yang hangat dan tenteram. Tanpa ketenteraman akan sukar bagi anak untuk belajar. Ketegangan dan ketakutan adalah wadah buruk bagi perkembangan karakter anak.

b) Menjadi panutan yang positif bagi anak sebab anak belajar dari apa yang dilihatnya, bukan dari apa yang didengarnya.

c) Mendidik anak berarti mengajarkan karakter yang baik dan mendisiplinkan anak agar berperilaku sesuai dengan yang diinginkan. ${ }^{43}$

Pada generasi sebelumnya, pengasuhan anak cenderung dilimpahkan pada ibu saja. Namun saat ini terjadi pergeseran konsep, dari pengasuhan motherhood menjadi parenthood. Konsep parenthood menitikberatkan pada peran kedua orang tua atau ayahibu. Dengan pergeseran konsep ini keterlibatan ayah dalam pengasuhan semakin besar. Ayah yang menjalankan pengasuhan secara optimal sangat mempengaruhi perkembangan dan karakter anak.

${ }^{42}$ Zubaedi, Disain Pendidikan KarakterKonsepsi dan Aplikasinya dalam Lembaga Pendidikan,... h. 112-

${ }^{43}$ Mukti Amini, Pengasuhan Ayah Ibu yang Patut : Kunci Sukses Membangun Karakter Anak, (Yogyakarta : Tiara Wacana, 2008), h. 108 
Anak memerlukan figur ayah dan ibu secara komplementatif bagi pengembangan karakternya. Hal ini karena peran ayah yang khas sulit digantikan oleh perempuan. Peran ayah diperlukan baik bagi anak laki-laki maupun anak perempuan. Bagi anak perempuan ayah merupakan tempat ia belajar hal yang biasanya dominan pada laki-laki, seperti kekuatan dan ketegaran, keruntutan berpikir, pengendalian emosi, dan kepemimpinan. Berdasarkan penelitian, anak perempuan yang dekat dengan ayahn akan memiliki keinginan berprestasi tinggi dan berani bersaing. Anak perempuan yang seperti ini akan cenderung terhindar dari hubungan pacarann yang tidak sehat karena dapat menghargai diri sendiri sebagaimana ayah menghargai dirinya. Sementara bagi anak laki-laki, ayah dapat menjadi contoh baginya untuk belajr bagaimana berkata, bersikap, berperilaku dan berpikir sebagai seorang laki-laki. Dari ayah anak laki-laki belajar bagaimana cara bergaul, cara memimpin orang lain, cara memperlakukan perempuan, cara menyelesaikan masalah, dan cara mempertahankan pendapat. Anak laki-laki yang dekat dengan ayah peluang anak terjebak dalam masalah kenakalan remaja sangat kecil.

Ada beberapa hal yang dapat dilakukan ayah untuk mengasuh dalam mengembangkan karakter anak, di antaranya adalah ; a) menyediakan waktu untuk berinteraksi dengan anak walaupun hanya sebentar, b) Menghindari tingkah laku menghina, meremehkan, memarahi, dan memarahi karena akan menimbulkan perilaku yang agresif dan tidak kooperatif, c) Mengusahakan ikut terlibat secara aktif dalam mentransfer nilai-nilai yang baik saat bersama anak, d) Mengupayakan diri sebagai figur idola bagi anak-anaknya. ${ }^{44}$

Faktor penting lainnya yang mempengaruhi perkembangan karakter anak dalam keluarga adalah jenis pola asuh yang diterapkan orang tua pada anaknya. Pola asuh adalah pola interaksi antara anak dan orang tua yang meliputi pemenuhan kebutuhan fisik (seperti makan dan minum), kebutuhan psikologis (seperti rasa aman dan kasih sayang), serta sosialisasi norma-norma yang berlaku di masyarakat. Menurut Hurlock ada tiga jenis pola asuh orang tua, yaitu ; a) pola asuh otoriter mempunyai ciri orang tua membuat semua keputusan, anak harus tunduk, patuh, dan tidak boleh bertanya, b) pola asuh demokratis mempunyai ciri orang tua mendorong anak untuk membicarakan apa yang ia inginkan, dan

${ }^{44}$ Mukti Amini, Pengasuhan Ayah Ibu yang Patut : Kunci Sukses Membangun Karakter Anak,... h. 118 
c) pola asuh permissif mempunyai ciri orang tua memberikan kebebasan penuh pada anak untuk berbuat. ${ }^{45}$

Pola asuh otoriter cenderung membatasi perilaku kasih sayang, sentuhan, dan kelekatan emosi orang tua-anak sehingga antara orang tua dan anak seakan memiliki dinding pembatas yang memisahkan "si otoriter" (orang tua) dengan "si patuh" (anak). Sebuah studi menunjukkan bahwa keluarga yang broken home, kurangnya kebersamaan dan interaksi antar keluarga, dan orang tua yang otoriter cenderung menghasilkan remaja yang bermasalah. Pola asuh permissif yang cenderung memberi kebebasan terhadap anak untuk berbuat apa saja sangat tidak kondusif bagi pembentukan karakter anak. Pola asuh demokratis tampaknya lebih kondusif dalam pendidikan karakter anak. Penelitian yang dilakukan Baumrind menunjukkan bahwa orang tua yang demokratis lebih mendukung perkembangan anak terutama dalam kemandirian dan tanggung jawab. Orang tua yang otoriter merugikan perkembangan anak, karena anak menjadi tidak mandiri, kurang bertanggung jawab dan agresif. Sedangkan orang tua yang permissif mengakibatkan anak kurang bisa menyesuaikan diri di luar rumah. Penelitian Arkoff menunjukkan anak yang dididik dengan cara demokratis umumnya cenderung mengungkapkan agresivitas dalam tindakan yang konstruktif atau dalam bentuk kebencian yang sifatnya sementara saja. Anak yang dididik dengan otoriter memiliki kecenderungan mengungkapkan agresivitasnya dalam bentuk tindakan yang merugikan. Sementara anak yang dididik secara permissif cenderung mengembangkan tingkah laku agresif secara terbuka dan terang-terangan.

Menurut Middlebrook hukuman fisik yang umumnya diterapkan dalam pola asuh otoriter kurang efektif untuk membentuk tingkah laku anak, karena ; a) menyebabkan marah dan frustasi, b) mengakibatkan perasaan menyakitkan yang mendorong tingkah laku agresif, c) akibat hukuman yang diterima anak dapat meluas sasarannya, misalnya anak menahan diri untuk memukul atau merusak pada waktu ada orang tua, tetapi segera melakukan setelah orang tua tidak ada, d) tingkah laku agresif orang tua menjadi model bagi anak. ${ }^{46}$

Pola asuh memiiliki peran yang sangat penting dalam membentuk karakter anak. Dalam pola asuh seringkali orang tua yang (mungkin) secara tidak sengaja menanamkan

${ }^{45}$ Hurlock, Elizabeth B, Psikologi Perkembangan Suatu Pendekatan Sepanjang Rentang Kehidupan,... h.

${ }^{46}$ Melly Latifah, Peranan Keluarga dalam Pendidikan Karakter Anak,... h. 5 
program negatif ke pikiran bawah sadar anak, akan terus mengendalikan hidupnya dan membuatnya menjadi berantakan di masa depan. Jika ingin membentuk karakter anak yang baik, sebaiknya hindarilah pola asuh yang salah. Seperti yang diungkapkan oleh Dorothy Law Nollte :

Jika anak dibesarkan dengan celaan,

Maka ia belajar memaki

Jika anak dibesarkan dengan permusuhan,

Maka ia belajar berkelahi

Jika anak dibesarkan dengan cemoohan,

Maka ia belajar rendah diri

Jika anak dibesarkan dengan penghinaan,

Maka ia belajar menyesali diri

Jika anak dibesarkan dengan toleransi,

Maka ia belajar mengendalikan diri

Jika anak dibesarkan dengan motivasi

Maka ia belajar percaya diri

Jika anak dibesarkan dengan kelembutan,

Maka ia belajar menghargai

Jika anak dibesarkan dengan rasa aman,

Maka ia belajar percaya

Jika anak dibesarkan dengan dukungan,

Maka ia belajar menghargai diri sendiri

Jika anak dibesarkan dengan kasih sayang dan persahabatan,

Maka ia belajar menemukan kasih dalam hidupnya ${ }^{47}$

Ada dua metode yang ditawarkan al-Ghazali untuk merubah tingkah laku manusia sehingga melahirkan akhlak yang baik, yaitu :

a) Metode mujahadah (menahan diri) dan metode riyadhah (melatih diri), seseorang harus harus berusaha keras untuk melakukan perbuatan-perbuatan yang bersumberkan pada akhlak yang baik, sehingga hal itu menjadi kebiasaan dan sebagai sesuatu yang menyenangkan. Metode pembiasaan ( $i^{\prime}$ tiyad) ini dipandang sebagai cara yang paling efektif untuk mencapai sifat jiwa yang sehat.

b) Metode pertemanan atau pergaulan, metode ini didasarkan pada asumsi bahwa manusia memiliki tabiat meniru. Jika seseorang bergaul dengan orang yang saleh dan baik, akan tumbuh kebaikan-kebaikan dalam dirinya. ${ }^{48}$

Lebih jauh al-Ghazali mengatakan bahwa sifat-sifat buruk yang ada dalam diri seseorang harus dilawan dengan ilmu dan amal. Selain itu juga diperlukan kesabaran untuk

47 Timothy Wibowo, Success Begins with Character-Revolusi Pendidikan Karakter, (Surabaya : pendidikankarakter.com, 2016), h. 164-165

${ }^{48}$ Ajat Sudrajat, Pendidikan Moral dalam Perspektif Islam,... h. 27 
melawan kehendak nafsu. Kombinasi ketiga unsur tersebut (ilmu, amal, dan sabar) inilah yang dapat menghapus sifat-sifat buruk manusia.

Dalam rangka membangun akhlak yang baik dalam diri manusia, al-Ghazali juga menyarankan agar latihan moral dimulai sejak usia dini. Orang tua bertanggung jawab atas diri anak-anaknya. Bahkan ia mengatakan agar seorang anak diasuh dan disusukan oleh seorang perempuan yang saleh. Makanan berupa susu yang berasal dari sumber yang tidak halal akan mengarahkan tabiat anak ke arah yang buruk.

Dari penjelasan di atas dapat disimpulkan bahwa faktor-faktor yang mempengaruhi perkembangan karakter anak adalah dimulai dari basis keluarga yang kuat, keterlibatan ayah-ibu dalam pengasuhan anak (parenthood), pola asuh yang diterapkan oleh orang tua, pembiasaan, konsistensi, adanya reward and punishment, serta keteladanan. Selain itu yang perlu juga mendapat perhatian adalah faktor makanan yang dikonsumsi anak. Faktor makanan yang diperhatikan tidak hanya dari aspek gizi dan kesehatan, tapi perlu juga diperhatikan dari aspek kehalalannya baik kehalalan dari segi zat maupun kehalalan dari cara memperolehnya.

3. Model-model Pendidikan Akhlak/Karakter dalam Al-Qur'an

Ada beberapa model pendidikan akhlak dalam Al-Qur'an, ${ }^{49}$ di antaranya adalah :

a) Model perintah, model perintah yang terdapat dalam Al-Quran mengarahkan sikap dan tingkah laku manusia ke taraf yang lebih baik. Atau dengan kata lain, konten pendidikan yang berhubungan dengan perubahan individu banyak disampaikan dengan cara perintah. Meskipun manusia memiliki kecenderungan untuk memilih, namun dengan metode perintah cenderung mendorong manusia melakukan perintah, apalagi perintah-perintah itu juga disertai dengan janji-janji yang menyenangkan.

b) Model larangan, dalam pembahasan masalah akhlak, kalimat an-nahi lebih bermakna mutlaq, kontiniu, dan istimrar, karena larangan yang disebutkan pada masalah akhlak adalah merupakan penjelasan perkara-perkara buruk yang harus ditinggalkan. Bila larangan untuk mengerjakan sesuatu bisa dimaknai perintah untuk amalan sebaliknya. Seperti larangan untuk berdusta yang berarti perintah untuk berbuat jujur, larangan berbuat kasar dan kekerasan berarti perintah untuk beramal dengan sifat kasif dan sayang, dan seterusnya. Model pendidikan dengan larangan ini sangat penting diterapkan dalam dunia pendidikan Islam karena dapat dilihat sebagai bentuk

${ }^{49}$ Ulil Amri Syafri, Pendidikan Karakter Berbasis Al-Qur'an, (Jakarta : Rajagrafindo Persada, 2014), h. $99-148$ 
komunikasi Allah kepada manusia. Model larangan adalah bentuk pembatasan dan tidak memberikan kebebasan mutlak pada pelaku pendidikan.

c) Model targhib (motivasi), targhib menjadi model pendidikan yang memberi efek motivasi untuk beramal dan mempercayai sesuatu yang dijanjikan. Misalnya tentang kematian. Islam memberikan penjelasan yang sangat baik terkait tentang kematian, utamanya melalui targhib. Islam memotivasi manusia untuk beriman dan beramal salehs erta melakukan perbuatan-perbuatan baik lainnya, dengan didasari keimanan sebagai modal untuk memasuki alam kematian. Melalui pendidikan yang memberi motivasi degan janji-janji yang terdapat dalam nash, maka sesuatu yang menakutkan bisa menjadi dirindukan dan diharapkan.

d) Model tarhib (menakut-nakuti), dalam al-Qur'an tarhib adalah upaya menakut-nakuti manusia agar menjauhi larangan dan meninggalkan suatu perbuatan. Semua tarhib yang disampaikan Allah kepada manusia bersifat ancaman yang disampaikan dalam proses mendidik manusia. Tarhib bukan hukuman. Tarhib berbeda dengan hukuman, Tarhib adalah proses atau meode dalam menyampaikan hukuman dan tarhib itu sendiri ada sebelum suatu peristiwa terjadi. Sedangkan hukuman adalah wujud ancaman yang ada setelah peristiwa itu terjadi.

e) Model kisah, merupakan sarana yang mudah untuk mendidik manusia. Model ini sangat banyak dijumpai dalam al-Qur'an. Kisah yang diungkapkan dalam al-Qur'an ini mengiringi berbagai aspek pendidikan yang dibutuhkan manusia, salah satu adalah aspek akhlak. Abdurrahman an-Nahlawy berpendapat bahwa metode kisah yang terdapat dalam al-Qur'an mempunyai sisi keistimewaan dalam proses pendidikan dan pembiasaan. Menurutnya, metode kisah dalam al-Qur'an memberikan efek positif pada perubahan sikap dan perbaikan niat atau motivasi.

f) Model dialog dan debat, pendidikan dan pembinaan dalam al-Qur'an juga menggunakan model dialog dan debat dengan berbagai variasi yang indah, sehingga pembaca menikmati keindahan tersebut. Tidak sedikit dari para pembaca merasa ikut terlibat langsung dalam model dialog-dialog yang ditampilkan al-Qur'an.

g) Model pembiasaan, ayat-ayat al-Qur'an yang menekankan pentingnya pembiasaan bisa terlihat pada term 'amilus shalihat. Term ini diungkapkan al-Qur'an sebanyak 73 kali. Bisa diterjemahkan dengan kalimat "mereka selalu melakukan amal kebaikan" atau "membiasakan beramal saleh". Jumlah term 'amilus shalihat yang banyak tersebut memperlihatkan pentingnya pembiasaan suatu amal kebaikan dalam proses 
pendidikan karakter dalam Islam. Al-Qur'an memberi penghargaan yang istimewa dalam bentuk berita gembira dan diiringi pujian Allah pada orang yang beramal saleh.

h) Model qudwah (teladan), merupakan aspek penting dalam proses pendidikan. Qudwah berasal dari huruf ق-دؤ yang berarti uswah (ikutan/teladan). Uswah disini dimaknai sebagai uswah hasanah dan uswah sayyi'ah. Dalam Islam sering digunakan istilah qudwah hasanah untuk menggambarkan keteladanan yang baik. Dalam model ini pendidik dituntut memiliki kepribadian yang baik agar menjadi cermin bagi peserta didik. Contoh model pendidikan qudwah yang paling berhasil adalah pendidikan Rasulullas SAW, di mana pendidikan langsung berpusat pada diri beliau dengan menampilkan keteladanan dalam berbagai aspek. Sebagaimana yang terdapat dalam QS al-Ahzab ayat 21 :

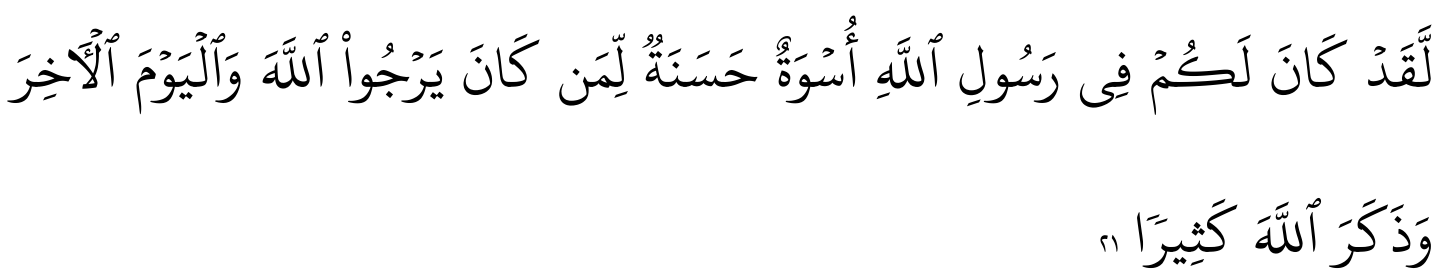

Artinya : "Sesungguhnya telah ada pada (diri) Rasulullah itu suri teladan yang baik bagimu (yaitu) bagi orang yang mengharap (rahmat) Allah dan (kedatangan) hari kiamat dan Dia banyak menyebut Allah."

Beberapa model tersebut penerapannya dapat digabungkan dengan metode yang ditawarkan oleh al-Ghazali. Misalnya metode mujahadah (menahan diri) dapat dilakukan melalui an-nahi (larangan), tarhib (menakut-nakuti), serta dialog dan debat. Dialog dan debat dalam perkembangan moral disebut pendekatan klarifikasi nilai-nilai, ${ }^{50}$ yaitu pendekatan yang memberikan pengalaman belajar bagi anak melalui proses menganalisis secara mendalam tentang nilai-nilai. Anak diberi kesempatan untuk menemukan, memilih, dan menganalisis kemudian berusaha menginternalisasikan nilai-nilai tersebut ke dalam dirinya dan menjalankannya dalam kehidupannya. Dengan pendekatan ini diharapkan adanya kesadaran akan konsekuensi pemilihan nilai, menyebarkan nilai-nilai tersebut, menghargai nilai-nilai tersebut, dan melakukan sesuatu sesuai dengan nilai-nilai tersebut dalam kehidupan nyata. Selain itu dapat juga dilakukan melalui pendekatan dilema moral, ${ }^{51}$ yaitu pendekatan yang menghadapkan anak pada dilema yang konfrontatif.

${ }^{50}$ Elida Prayitno, Perkembangan Remaja, (Padang : FIP UNP, 2002), h. 111

${ }^{51}$ Ibid. 
Kemudian anak diberi kesempatan untuk mengemukakan pendapat, alasan, opini, dan tanggapan. Anak diarahkan untuk menilai alasan-alasan dan pendapat-pendapat yang lebih baik untuk mengatasi dilema tersebut.

Dari beberapa model di atas, model manakah yang cocok diterapkan untuk anakanak dan model manakah yang cocok diterapkan pada remaja? Semua model yang ditawarkan di atas cocok diterapkan baik pada anak-anak maupun pada remaja. Yang membedakannya adalah metode dan pendekatannya. Sesuai dengan teori social-learning perkembangan karakter berlangsung melalui proses latihan dan peniruan. Maka pada usia anak-anak untuk membantu perkembangan karakter yang baik orang tua dan guru perlu melatih anak dan memberi contoh yang baik. Sedangkan pada masa remaja membutuhkan role-model baginya dalam mengidentifikasi diri. Orang tua dan guru diharapkan dapat menjadi role-model yang ideal bagi remaja.

Menurut teori kognitif perkembangan karakter erat kaitannya dengan perkembangan kognitif. Kemampuan anak memahami nilai-nilai dan merealisasikan nilainilai tersebut dalam kehidupan nyata sangat tergantung pada pemahaman anak terhadap nilai-nilai tersebut. Karena itu pada usia anak-anak, orang tua dan guru dalam memperkenalkan nilai-nilai dapat melalui metode kisah (bercerita). Sedangkan pada masa remaja dengan kemampuan kognitif yang sudah berkembang sampai pada tahap operasional formal, memungkinkan remaja semakin memahami nilai-nilai yang abstrak. Artinya semakin tinggi pemahaman remaja tentang nilai-nilai yang abstrak, remaja diharapkan semakin memiliki karakter sesuai dengan nilai-nilai tersebut. Tetapi kenapa yang terjadi malah sebaliknya? Kemungkinan ada bebera faktor penyebabnya, di antaranya : tidak ada pembiasaan dari kecil, tidak pernah mengklarifikasi nilai-nilai apakah yang dipahaminya benar atau tidak, pengaruh pergaulan dengan teman sebaya, serta kekecewaan tentang nilai-nilai yang dipahaminya bertentangan dengan apa yang terjadi dalam kehidupan masyarakat. Oleh karena itu diperlukan pendekatan yang komprehensif dalam pendidikan karakter.

\section{E. Kesimpulan}

Dari uraian di atas dapat ditarik beberapa kesimpulan sebagai berikut ; pertama, karakter merupakan serangkaian sikap, perilaku, motivasi, dan keterampilan untuk melakukan hal yang terbaik. Karakter yang baik harus didukung oleh pengetahuan tentang kebaikan (knowing the good), keinginan untuk berbuat baik (desiring the good), dan kemampuan untuk melakukan perbuatan baik (doing the good). 
Kedua, dalam al-Qur'an konsep karakter menggunakan term “akhlak”. Akhlak adalah kehendak yang dibiasakan. Kehendak merupakan ketentuan dari beberapa keinginan manusia setelah bimbang. Sedangkan kebiasaan merupakan perbuatan yang diulang-ulang sehingga mudah melakukannya. Masing-masing dari kehendak dan kebiasaan ini mempunyai kekuatan, dan gabungan dari kehendak dan kebiasaan ini menimbulkan kekuatan yang lebih besar. Kekuatan yang besar inilah yang disebut akhlak. Apabila kebiasaan menghasilkan suatu perbuatan baik disebut akhlakul karimah. Pendidikan karakter berbasis al-Qur'an pada dasarnya dibangun melalui tiga dimensi akhlak, yaitu ; akhlak pada Allah, akhlak pada diri sendiri, serta akhlak pada sesama manusia dan lingkungan.

Ketiga, faktor-faktor yang mempengaruhi perkembangan karakter anak adalah dimulai dari basis keluarga yang kuat, keterlibatan ayah-ibu dalam pengasuhan anak (parenthood), pola asuh yang diterapkan oleh orang tua, pembiasaan, konsistensi, adanya reward and punishment, serta keteladanan. Selain itu yang perlu juga mendapat perhatian adalah faktor makanan yang dikonsumsi anak. Faktor makanan yang diperhatikan tidak hanya dari aspek gizi dan kesehatan, tapi perlu juga diperhatikan dari aspek kehalalannya, baik kehalalan dari segi zat maupun kehalalan dari cara memperolehnya.

Keempat, pendidikan karakter merupakan usaha secara sengaja untuk membantu pengembangan karakter dengan optimal. Pendidikan karakter tidak bisa hanya sekedar mentransfer ilmu pengetahuan atau melatih suatu keterampilan tertentu. Pendidikan karakter perlu proses, contoh teladan, dan pembiasaan atau pembudayaan dalam lingkungan peserta didik di lingkungan sekolah, keluarga, maupun lingkungan masyarakat. Pendidikan karakter dalam al-Qur'an perlu memperhatikan pentingnya dimensi penanaman akhlak terpuji (akhlakul karimah).

Kelima, dalam mengembangkan karakter melalui pendidikan formal, harus didasarkan pada beberapa prinsip dan strategi. Di antaranya adalah ; a) menggunakan prinsip keteladanan dari semua pihak, baik orang tua, guru, masyarakat maupun pemimpin, b) menggunakan prinsip kontiniutas dan rutinitas, yaitu pembiasaan terus menerus dalam segala aspek kehidupan, dan c) menggunakan prinsip kesadaran, yaitu kesadaran untuk bertindak sesuai dengan nilai-nilai karakter yang diajarkan. Salah satu strategi yang sangat perlu diperhatikan dalam pendidikan karakter adalah menciptakan lingkungan belajar yang kondusif sehingga anak dapat belajar dengan efektif di dalam suasana yang memberikan rasa aman, penghargaan tanpa ancaman, dan memberikan semangat. 